\title{
Molecular aspects of prostate cancer
}

\author{
M. V. Cronauer $\cdot$ Z. Culig
}

Received: 25 February 2012 / Accepted: 27 February 2012 / Published online: 7 March 2012

(C) Springer-Verlag 2012

Molecular biology has altered the face of biomedical research. Due to new techniques in molecular biology, our knowledge of pathological processes has grown exponentially over the last decades. Today, cancer research has become a multidisciplinary task, requiring basic scientists as well as clinicians. However, only when scientists and clinicians bridge the gap between laboratory and clinic, a rapid translation of the experimental findings to the clinic will take place.

For a long time, progression of prostate cancer $(\mathrm{PCa})$ was explained with loss of androgen receptor (AR) expression. After years of research, it became clear that the AR plays a crucial role in recurrent PCa. New therapies that interfere with androgen signalling have been developed after many years of performing laboratory research on the AR. In the following special issue "Molecular aspects of prostate cancer", the World Journal of Urology offers a unique collection of reviews and original papers highlighting recent developments in $\mathrm{PCa}$ research.

Prostate cancer $(\mathrm{PCa})$ is the second most frequently diagnosed cancer worldwide [1]. While treatment of organconfined $\mathrm{PCa}$ involves radical prostatectomy or radiation therapy, current treatment for advanced PCa is mainly based on androgen ablation therapies like chemical or surgical castration and/or the application of anti-androgens. One main obstacle in the treatment of advanced PCa is the

M. V. Cronauer $(\square)$

Department of Urology, University of Ulm,

Prittwitzstrasse 43, 89075 Ulm, Germany

e-mail:marcus.cronauer@uni-ulm.de

\section{Z. Culig}

Department of Urology, Innsbruck Medical University,

Anichstrasse 35, 6020 Innsbruck, Austria

e-mail: zoran.culig@i-med.ac.at development of castration-resistant prostate cancer (CRPC) cells following androgen ablation therapy. In this special issue, two comprehensive reviews by Nadiminty et al. and Hodgson et al. summarize our current knowledge about the molecular mechanisms leading to sustained AR signalling in CRPC [2, 3]. In addition, Culig and Santer [4] present a very informative survey on the emerging field of AR-co-activators and their role in the initiation and progression of PCa. A further article of Jain et al. [5] highlights the importance of $\mathrm{NF}-\kappa \mathrm{B}$-signalling for the regulation of apoptotic pathways as well as AR signalling. The series of reviews is completed by a paper of Marianne Sadar [6] summarizing the latest advances in the development of small-molecule inhibitors of the AR. Classical as well as second-generation anti-androgens like MDV3100 or ARN-509 target the ligand-binding domain situated in the $\mathrm{C}$-terminus of the AR. With special emphasis on novel AR-antagonists targeting the N-terminal AR-transactivation domain, Sadar presents a novel revolutionary generation of AR-antagonists, able to inhibit deregulated full-length AR as well as constitutively active, $\mathrm{C}$-terminally truncated AR-variants recently identified in CRPC cells [7, 8].

The reviews of this special issue are complemented by a series of original articles. On the basis of ID4 expression, Vinarskaja et al. [9] document the limits and pitfalls of techniques used for the detection of methylation-based DNA-markers. In a preliminary study, the team of Stope et al. [10] provides first experimental evidence that the small heat shock protein HSP27 is not only involved in folding and stability of client proteins but has also an impact on the regulation of messenger RNA in PCa cells. Finally, Streicher et al. [11] present an experimental model system designed to select next-generation AR-antagonists targeting the N-terminus of the AR as described by Sadar in this issue. 
There is no doubt that molecular biology will continue to have a tremendous impact on diagnosis, treatment and prevention of PCa. Although we are aware that the present selection of papers reflects only a small area of PCa molecular biology, we hope that both, clinicians as well as basic scientists, will enjoy reading the articles of this topic issue.

\section{Conflict of interest None.}

\section{References}

1. Jemal A, Bray F, Center MM, Ferlay J, Ward E, Forman D (2011) Global cancer statistics. CA Cancer J Clin 61:69-90

2. Hodgson MC, Bowden WA, Agoulnik IU (2011) Androgen receptor footprint on the way to prostate cancer progression. World J Urol. doi:10.1007/s00345-011-0743-7

3. Nadiminty N, Gao AC (2011) Mechanisms of persistent activation of the androgen receptor in CRPC: recent advances and future perspectives. World J Urol. doi:10.1007/s00345-011-0771-3

4. Culig Z, Santer FR (2011) Androgen receptor co-activators in the regulation of cellular events in prostate cancer. World J Urol. doi:10.1007/s00345-011-0797-6

5. Jain G, Cronauer MV, Schrader M, Möller P, Marienfeld RB (2011) NF- $\kappa$ B signaling in prostate cancer: a promising therapeutic target? World J Urol. doi:10.1007/s00345-011-0792-y
6. Sadar MD (2011) Advances in small molecule inhibitors of androgen receptor for the treatment of advanced prostate cancer. World J Urol. doi:10.1007/s00345-011-0745-5

7. Hu R, Dunn TA, Wei S, Isharwal S, Veltri RW, Humphreys E, Han M, Partin AW, Vessella RL, Isaacs WB, Bova GS, Luo J (2009) Ligand-independent androgen receptor variants derived from splicing of cryptic exons signify hormone-refractory prostate cancer. Cancer Res 69:16-22

8. Zhang X, Morrissey C, Sun S, Ketchandji M, Nelson PS, True LD, Vakar-Lopez F, Vessella RL, Plymate SR (2011) Androgen receptor variants occur frequently in castration resistant prostate cancer metastases. PLoS ONE 6(11):e27970

9. Vinarskaja A, Goering W, Ingenwerth M, Schulz WA (2011) ID4 is frequently downregulated and partially hypermethylated in prostate cancer. World J Urol. doi:10.1007/s00345-011-0750-8

10. Stope MB, Schubert T, Staar D, Rönnau C, Streitbörger A, Kroeger N, Kubisch C, Zimmermann U, Walther R, Burchardt M (2012) Effect of the heat shock protein HSP27 on androgen receptor expression and function in prostate cancer cells. World J Urol. doi:10.1007/s00345-012-0843-Z

11. Streicher W, Zengerling F, Laschak M, Weidemann W, Höpfner M, Schrader AJ, Jentzmik F, Schrader M, Cronauer MV (2012) AR-Q640X, a model to study the effects of constitutively active $\mathrm{C}$-terminally truncated AR-variants in prostate cancer cells. World J Urol. doi:10.1007/s00345-012-0842-0 